\title{
Geology and mining of selected energy resources in China
}

\author{
Stanisław Roman Ćmiel ${ }^{*}$ \\ University of Silesia, Sosnowiec, Poland; *stanislaw.cmiel@us.edu.pl
}

\begin{abstract}
The article presents geological and economic characteristics of energy resources and their mining in China. Coal basins are associated with the Palaeozoic and Mesozoic fold structures connecting crystalline massifs of the Chinese Platform. In China four coal-bearing regions are delimited: the most important economically central region (Shanxi and Ordos Basin) as well as eastern, south-western and western (Xingjian). In terms of coal resources, China ranks third, and in terms of the extraction - first in the world, producing approx. 3.65 billion $\mathrm{t} \mathrm{a}^{-1}$. In the twenty-first century Chinese mining industry has undergone restructuring involving the liquidation of small, technologically backward mines with poor safety and profitability record. The most important onshore oil and gas basins occur in Daqing, Shengli, Nanyang, Renqiu, Karamay, Dagang and Yumen, while offshore basins are in the Yellow Sea and South China Sea. In terms of crude oil consumption and import China takes the first place in the world. Natural gas plays a relatively small role in energy production. China has the largest shale gas reserves in the world $\left(36\right.$ trillion $\left.\mathrm{m}^{3}\right)$ and it is intensively preparing for their extraction.
\end{abstract}

Key words: China, geology, mining, energy resources

\section{Introduction}

In terms of coal resources Asia is the richest continent. It has numerous large basins both in terms of their area and volume of resources. Asia's geological resources are estimated at about 8.1 trillion tons, of which coal accounts for 5.9 trillion tons (including 600 billion tons of coking coals). Balance resources amount to 345 billion tons, of which 138 billion tons are suitable for opencast mining. In Asia most coal mining and coal consumption takes place in China, the Asian part of the Commonwealth of Independent States, India, both North and South Korea, Japan and Vietnam. Coal in China has become one of the most important pillars of the country's power. It is therefore important to look at its current position.

China coal basins are associated with the Palaeozoic and Mesozoic fold structures connecting the crystalline massifs of the China platform with depressions within these massifs (Fig. 1).

In terms of stratigraphy China's industrial coal deposits are found in the sediments of all geological periods, but the most important are primarily associated with the Carboniferous and Permian as well as Jurassic and Tertiary deposits. The largest basins and beds containing $3 / 4$ of the resources are in the
Permian-Carboniferous deposits of the northern and north-eastern parts of the country. The most favourable conditions for the formation of coal were in the Upper Carboniferous, when thick beds developed in large areas in the provinces of Shaanxi (11), Shanxi (6), Hubei (12), Shandong (8) and Neimenggu (4) [Inner Mongolia] (Fig. 2).

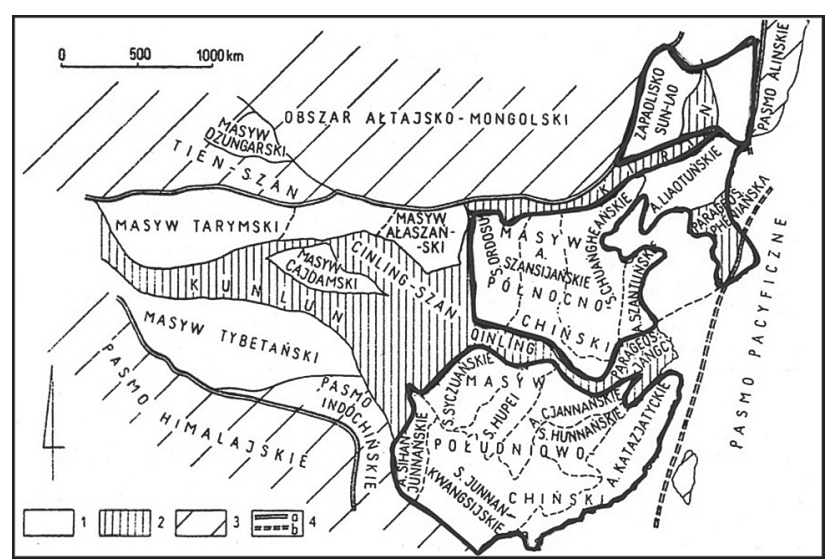

Fig. 1. Geology of China (after E. Stupnicka 1978, modified) 1 - Precambrian crystalline massifs, 2 - Paleozoic fold structures of the Chinese Platform, 3 - fold structures, 4 - platform boundaries 
Of these the most productive is the Upper Carboniferous Taiyuan series. The Permian coal-bearing deposits, which vary greatly in time and space, are found in northern and southern China. The Lower Permian deposits, represented by the best quality Shanxi coal series, mainly occur in the northern part of China, having secondary importance in the southern part of the country. In contrast, the Upper Permian Loping series occurs mainly in the southern part. The main coal-bearing provinces are the Shaanxi (11) and Shanxi (6) with the largest basins Datong, Yangquan and Xishan; Habei (5) with the basin Kailuan as well as Inner Mongolia (4). Other economically important deposits also include Fuxin from the Jurassic as well as Fushun in Liaoning Province (3) and Hegang in Hejlongjiang Province (1) from the Paleogene.

The coal-bearing Mesozoic deposits are mainly related to the Lower Triassic, Lower Jurassic and Lower Cretaceous. Despite the fact that they occur in nearly all provinces their stratigraphy and coal-bearing features are not that well recognised compared to the Palaeozoic deposits. The largest Lower Triassic deposits occur in the following provinces: in the south-western part of the country - Yunnan (22), Sichuan (23), south-eastern - Jangxi (16), SW - Xinjiang (26) and Tibet (27) and north-eastern - Neimenggu (4). The Upper Triassic coal-bearing deposits are found only in the south-western part of China, mainly in Yunnan Province (22) and are connected with the South China Massif.

The Lower Jurassic deposits stretch mainly in the northern and southern China. Most of the deposits of this period are small, creating isolated zone of the north-east to south-west course. Especially notewor-

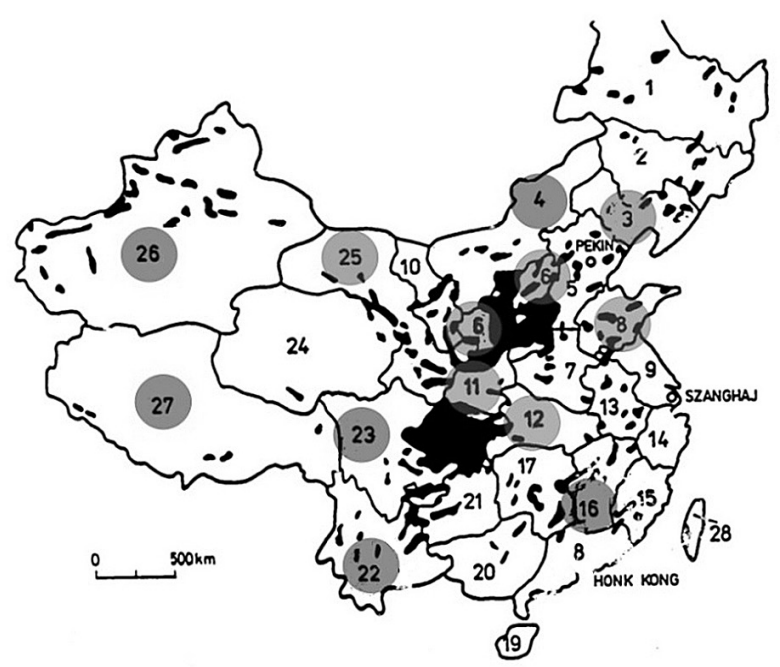

Fig. 2. Distribution of coal deposits and basins in China by provinces (after W. Gabzdyl 1994, modified)

The main coal basins: 6, 8, 11, 12 - Carboniferous, 3, 25 - Permian, 16, 22, 23, 26, 27 - Triassic thy are the deposits of the provinces Liaoning (3), Sichuan (23) and Xinjiang (26).

The Lower Cretaceous deposits are characterised by low coal-bearing and are known mostly from the provinces Heilongjiang (1), Jilin (2), Sichuan (23) and Fujian (15).

The Cenozoic deposits occur mainly in the east, along the Pacific coast forming two zones: northern being an extension of the coal-bearing deposits of Japan, Korea and the Far East of Russia, i.e. Heilongjiang (1), Jilin (2) and Liaoning (3), and southern which is part of the coal-bearing area of the tropics, i.e. Taiwan (28), Guangdong (18), Jangxi (16) and Yunnan (22) (Fig. 2). What is also characteristic is the diversity of the coal-bearing Cenozoic stratigraphic profile. In the north-eastern part of China they are found in the Paleogene deposits, while in the south in the Neogene deposits. In terms of their quality Chinese coals are not well recognised. It is understood that there are all kinds of coals from lignite to anthracites, predominantly bituminous coals. China's geological resources are estimated at about 1.4, or even 6 trillion tones), while the documented deposits in the managed (balance) deposits - at 114.5 billion tons, of which 62.2 billion tons are bituminous coals (3rd place in the world). The volume of the resources in the individual provinces is presented in Fig. 3.

Mining in China accounts for half of the global extraction and amounts to 3.65 billion tons of coal per year (first place in the world) and is almost entirely used by China (world extraction in $2011-6.7$ billion tons, 2013 - 7.2 billion t) (BP Energy Review, 2013). Coal mining in China is growing annually by about 5\%. Coal import amounted to 150 million tons in 2012 and is projected to increase (2013 - 284 million tons).

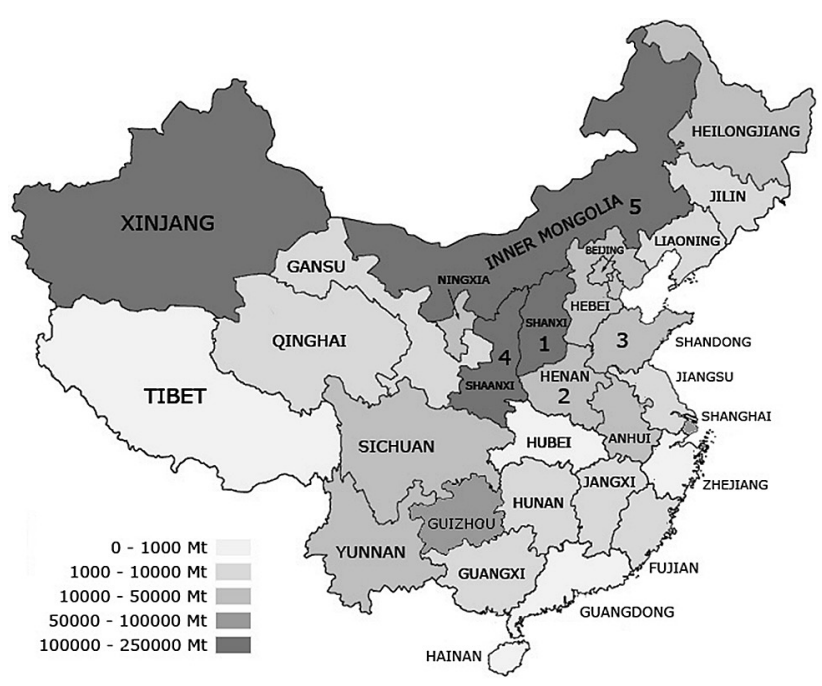

Fig. 3. Coal resources in China by provinces (after www. mincom.home.pl) 


\section{China's coal-bearing regions}

In terms of distribution of deposits there are four coal-bearing regions of China: central (Shanxi and Ordos Basin), north-eastern, south-western and western (Xinjiang) (Fig. 4) The central area is associated with the North China Massif, i.e. the Shanxi anticline and in fact it needs to be considered as a single Upper Palaeozoic coal-bearing area, which due to various geological processes has been divided into isolated basins and deposits. Here are the largest basins and deposits in China, located in Shanxi Province (6), such as Datong with the deposits of 2.6 billion tons, Yangquan with 2.47 billion tons and Xishan with 1.67 billion tons.

The China's largest coal-bearing province is the province of Shanxi, whose area of 157.1 thousand $\mathrm{km}^{2}$ is one big coal-bearing area of the resource balance representing $30 \%$ of the China's deposits, i.e. over 200 billion tones, and giving $38 \%$ of the national extraction. The region has 10 basins, in five of which mining is developed. Extraction is conducted in about 5,580 small and large mines, giving about 1.38 billion tons of coal a year. Datong is the largest basin with an area of $2,200 \mathrm{~km}^{2}$, located to the south east of Beijing. Coal-bearing deposits belong to the Upper

\section{Coal production and consumption}

China is the world's largest producer and consumer of coal.

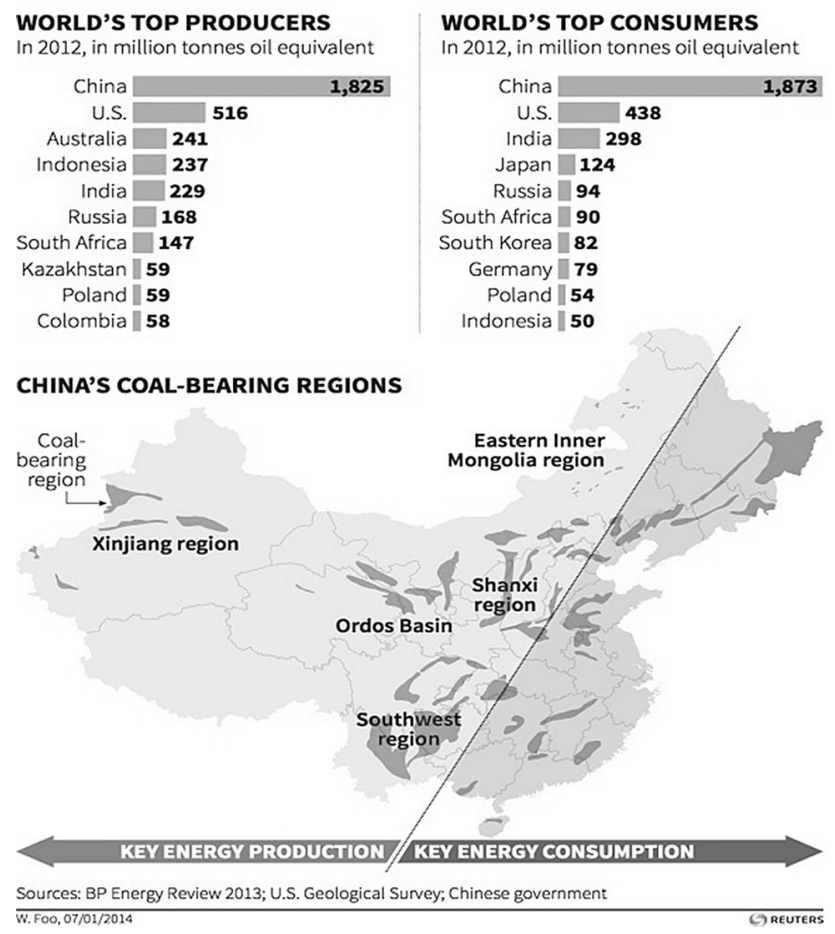

Fig. 4. Coal-bearing regions, mining and coal consumption in China in 2012 (after BP Energy Review, 2013)

Converter $-1 \mathrm{t}$ of oil $=2.7$ tons of coal.
Carboniferous Taiyuan series, Lower Permian Shanxi series as well as Lower and Middle Jurassic series of Datong and Jugan. The most productive are the series of Taiyuan and Datong. In terms of its structure the basin is an asymmetric anticline with the north-east to south-west extent. In the Taiyuan series there are three coal seams 1.5 to $3 \mathrm{~m}$ thick, and in the Datong series there are 30 seams, of which seven are up to $5.7 \mathrm{~m}$ thick. The total thickness of the coal seams in this series is $26 \mathrm{~m}$. The coals of the central region are bituminous coals. The resources of the basin are estimated at 2.6 billion tons, and the extraction is 35 million tones a year.

The north-eastern region is associated with the Manchuria Massif, and lithologically with the Jurassic and Oligocene coal-bearing formation. The main provinces are Inner Mongolia (4) and Liaoning (3) (Fig. 3). The biggest basins of this region include Fuxin and Fushun located in Liaoning Province (3) on the Manchurian Plain (the province is also known for its unique past fauna sites, which include complete specimens of feathered dinosaurs, sinosauropteryxes, with preserved stomach contents and two non-laid eggs). In the Fuxin Basin on the crystalline substrate there are coal-bearing deposits of the Upper Jurassic over $4 \mathrm{~km}$ thick. They are built of sandstones, clays and coal seams with total thickness of up to $90 \mathrm{~m}$. The basin is in the tectonic rift with two synclines dissected with a large network of faults and igneous intrusions. The extraction of more than 10 million $\mathrm{a}^{-1}$ is carried out by open pit mining. These are coals of different carbon content of the resources estimated at 430 billion tons. The Fushun deposit is located to the east of Fuxin in the area of Mukden. The deposit extraction has been carried out since 1914. The seam is developed in the form of a trough, whose substrate is granitic gneiss. The Oligocene deposits of the bipartite Fushun series are coal-bearing. The lower part, about $240 \mathrm{~m}$ thick series composed of sandstones, claystones and tuffs, contains two coal seams. This part is separated from the upper seam by a basalt bed. The upper part contains the main coal seam of the thickness from 10 to $200 \mathrm{~m}$, a series of oil shale $120-180 \mathrm{~m}$ thick and calcareous marl of a thickness of up to $900 \mathrm{~m}$.

In the south-western region, connected with the South China Massif, the highest coal-bearing deposits are from the Upper Permian and Lower Jurassic. The most important deposits include Loping (Jangxi Province [16]), Liunan (Fuijan [15]) and Zhaotung (Yunnan [22]). In the western region in Xingjiang Autonomous District (26) the coal-bearing deposits are of various ages but the Mesozoic ones dominate. Especially noteworthy are coking coals occurring here, as one of its seams is $120 \mathrm{~m}$ thick. 


\section{Coal mining in China}

In 2012 China extracted 3.65 billion tons of coal (including 320 million tons of lignite) representing $48 \%$ of the world production of this resource (2013 - 7.2 billion tons). Extraction grew rapidly: in 2007 it amounted to 2.3 billion tons, in $2009-2.5$ billion tons and in $2012-3.65$ billion tons, and over the next few years it is expected to increase by a further 100 million tons. Consumption totalled to 3.8 billion tones, including 570 million tons of coking coal, 3.07 billion tons coal for energy production and 160 million tons used in the chemical industry. Coal covers $70 \%$ of China's demand for energy resources, crude oil covers $15 \%$, but half of it is imported, while natural gas covers $5 \%$.

Until the twenty-first century coal mining was carried out in 25 thousand mines. This number included 16 thousand small mines which produced $40 \%$ of coal but utilised only $10-15 \%$ of the deposit. Due to their low level of investment, outdated mining techniques and a low level of security small mines showed low profitability and generated $2 / 3$ of mining accidents. Therefore, Chinese mines were considered the least safe in the world. They were responsible for about $80 \%$ of all fatalities in mining accidents in the world. The largest disaster in China occurred in 1942 during the Japanese occupation when in a Manchurian mine 1,572 people were killed. Since the beginning of the twenty-first century, coal mining in China has been undergoing intense restructuring. Its main aim was to eliminate smaller mines producing less than 30 thousand tons of coal a year as well as consolidate production groups in holdings of huge production capacity. As a result, eight holdings of the extraction capacity of over 100 million $\mathrm{a}^{-1}$ and 10 of the extraction capacity of over 50 million $\mathrm{a}^{-1}$ have been created, which together provide more than half of the national coal production.

Mine closures primarily concern the mines located in the provinces of Inner Mongolia, Shanxi and Shaanxi, which produce about $60 \%$ of coal extracted in China. During the first three years 11,155 mines were closed, i.e. $45 \%$ of all mines in China, and about 20,000 unlicensed mines are going to be closed by 2015 . Their closure will cause a significant increase in production in large state-owned corporations such as Shanxi Coal Coke Group Ltd, China Shenhua Energy Co., Yanzhon Coal Mining Co., China Coal Energy Co. and the biggest mining facilities such as Anhui-Huainan New District - 30 million $\mathrm{a}^{-1}$, Shanxi-Datong Mining District Tashan - 15 million $\mathrm{a}^{-1}$, Guizhou-Panjiang Mining District - 10 million $\mathrm{a}^{-1}$. Restructuring has also led to a decline in fatalities by half. According to official figures 6,424 miners died in 2003 (unofficially estimated at about 20 thousand per year). In 2006-2012 the number of fatalities decreased from 4,746 to 1,384 (a decrease by $70.8 \%$; in 2012 in the US mines there were 48 fatalities), and the number of fatalities per 1 million tons of extracted coal dropped from 2.04 to 0.347 . The restructuring also focuses on the development of transport, especially rail, because coal is consumed primarily in the most industrialised eastern coastal areas, while the deposits are located inland. China's balance of coal resources of slightly over 100 billion tons is sufficient for approx. quarter of a century. That is why China is also seeking suppliers of similar amounts of coal among the nearest neighbouring countries. For this reason, considerable financial resources have been invested in the Tavan Tolgoi deposit in Mongolia's Gobi Desert at a distance of about $270 \mathrm{~km}$ from the Chinese border. The deposit was discovered in 1945 by the Russians, and its resources are estimated at 125 billion tons available via opencast mining. The resources which have been documented and made available for mining amount to 7.5 billion tons, $25 \%$ of which is high-quality coking coal. The main shareholder in its exploitation is a Mongolian company Erdenes MGL and Minining Corporation. The coal seam was on a small scale operated since the 1960s. The right to its further exploitation is debated by all major coal states, while Mongolia wants diversification of investors so as not to be dominated by the Chinese neighbour. Bids were submitted by companies from the USA, China, Japan, South Korea and Russia. Regardless of who will get the main rights to its exploitation, almost all coal is going to be sold to China. The initial production on an industrial scale amounted to 15 million tons of coking coal, and ultimately is expected to reach 30 million tons in 2015. Rail lines to connect the mine with China and the Russian Baikal-Amur Mainline are being constructed. It is one of the reasons for the lower interest of China in the imports of coal from its existing suppliers (Australia and Indonesia). Until 2017 China will reduce coal consumption by over 80 million tons and by 2020 by about 160 million tons in the action to reduce air pollution. Coal is responsible for $80 \%$ of electricity generated in China.

\section{Deposits of crude oil and natural gas}

The deposits of hydrocarbons in China occur both onshore and offshore. The most important onshore deposits are in the basins Daqing, Shengli, Nanyang, Renqiu, Karamay, Dagang and Yumen, while the offshore ones are in the Yellow Sea and South China Sea (Fig. 5).

The South China Sea two projects are being implemented: Panyu and Enping Fields as well as the Pearl River Mouth Basin. After World War II, the oil industry in China was underdeveloped, so the coun- 


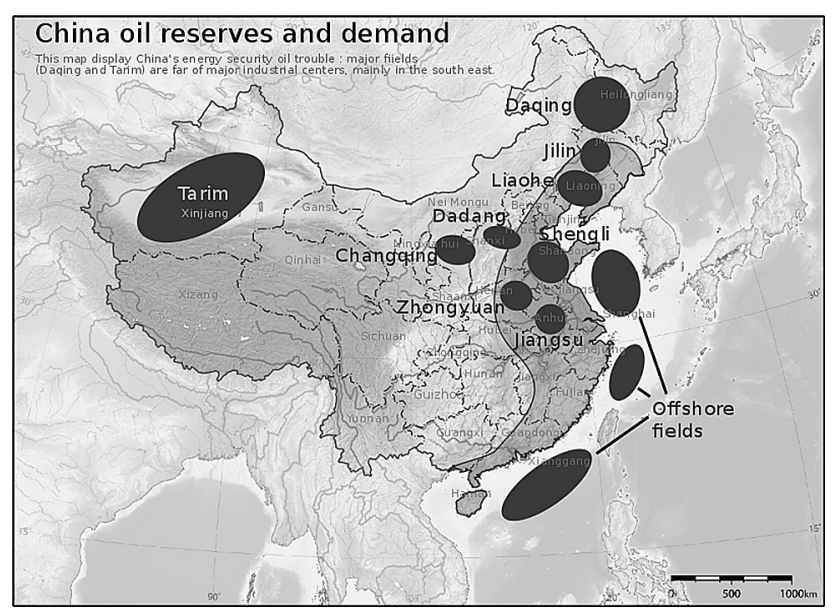

Fig. 5. Oil field resources and oil consumption (after www. nowastrategia.org.pl)

try imported oil from Malaysia, i.e. the then largest producer in the South China Sea Basin. To become independent, state-owned companies were established to deal with only exploration and documentation of oil and gas resources. Currently, the most important of them include the China National Offshore Oil Corporation, China National Petroleum Corporation, China National Refinery Corporation and Sinopec. Exploitation of hydrocarbons began in the early 1960s, when great oil reserves were discovered in the Songhua Jiang Liao Basin in north-eastern China in the Daqing Oilfield in Heilongjiang Province, later to be called the Daging Oil Region (Fig. 5). Crude oil extraction began in 1960, giving nearly 2.3 million tons of oil. In 1965 oil fields in Shengli, Shandong, Dagang and Tianji were opened, which helped nearly eliminate the need for its import. In 1973, when production increased, China began to export crude oil to Japan and began exploration on the shelf. Exports increased to 20 million tons in 1985, before the internal consumption began to grow faster than production. Until 1993, domestic demand for oil had exceeded domestic production and China became an oil importer. As a result it also started to invest in foreign reserves to secure oil supplies at a sufficiently high level. Domestic production meets $2 / 3$ of the domestic demand and it is estimated that China will need 600 million tons of oil by 2020 .

To guard against fluctuations in oil prices and foreign suppliers, in 2004 China introduced a national project of development of the oil industry, which is dealt with by the China National Petroleum Corporation. Three crude oil tanks were built. The first one, Zhoushan in Zhejiang Province, with the storage capacity of 5.2 million $\mathrm{m}^{3}$, was built by the company Sinopec, the largest company engaged in crude oil refining. The next tanks are Qingdao in Shangdong Province and Dalian in Liaoning Province. At the same time the search for new offshore oil fields was intensified. The result was the discovery of the Liuhua oil field, i.e. the largest oil field on the South China Sea. Crude oil production in China, which amounts to 209 million tons (2013) is far insufficient. In terms of consumption and oil imports, in 2013 China overtook the United States and now takes the 1st place in the world. In 2004, China imported 100 million tons of crude oil to supply the growing energy industry. More than half of the imports come from the Middle East and Russia's Central Siberian oil fields, as well as from Burma, Indonesia and Australia. Currently, oil reserves are estimated at 2.5 billion tons and with the consumption of 455 million tons of crude oil and import of over 200 million tons it is enough for about 12 years (Fig. 6)

Considering China's huge demand for energy, natural gas plays a relatively small role in its production (5\%), but it is expected that by 2020 it will provide $10-15 \%$ of energy. Conventional resources are estimated at 2.5 trillion $\mathrm{m}^{3}$. Over the past five years consumption, production and import of gas in China has recorded a double-digit growth. China produced 112 billion $\mathrm{m}^{3}$ of natural gas in 2013 , becoming the sixth largest producer in the world (at this time it consumed 170 billion $\mathrm{m}^{3}$ ). Gas production doubled in the period 2005-2013. Extraction of gas from conventional deposits is held together with crude oil (Fig. 5).

China has the largest shale gas reserves in the world (36 trillion $\mathrm{m}^{3}$ ) (www.lupkipolskie.pl) and is intensively preparing for their extraction (Fig. 7).

Some sources (Institute for Energy Studies) cast doubt on the volume of reserves in unconventional gas deposits, due to the very rough estimates of their size. Even if the resources prove to be smaller, they

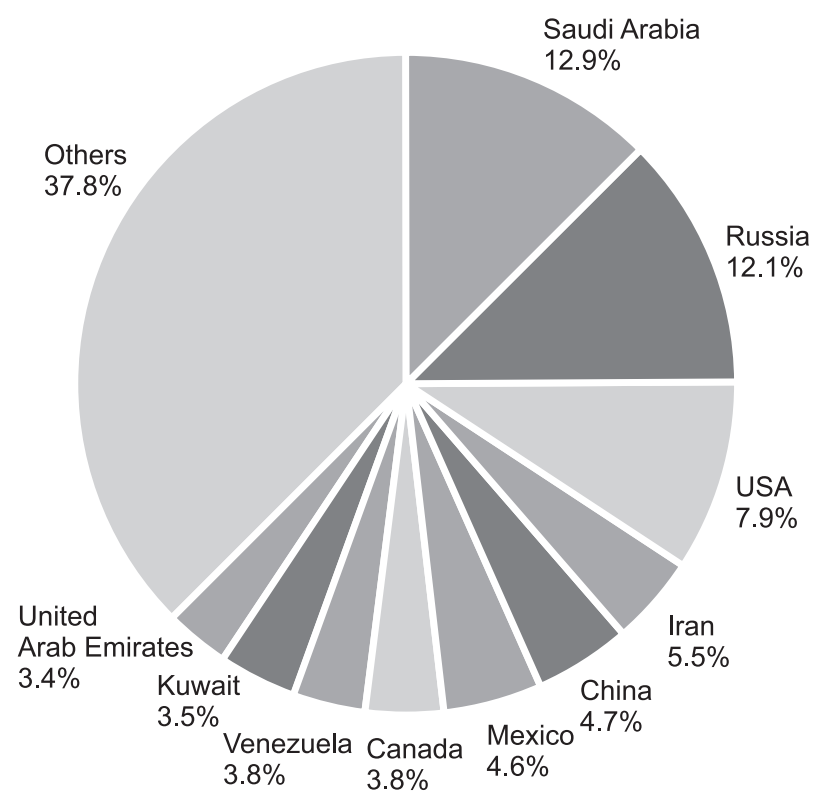

Fig. 6. Largest crude oil producers (after www.sendzimir. metal.agh.edu.pl) 


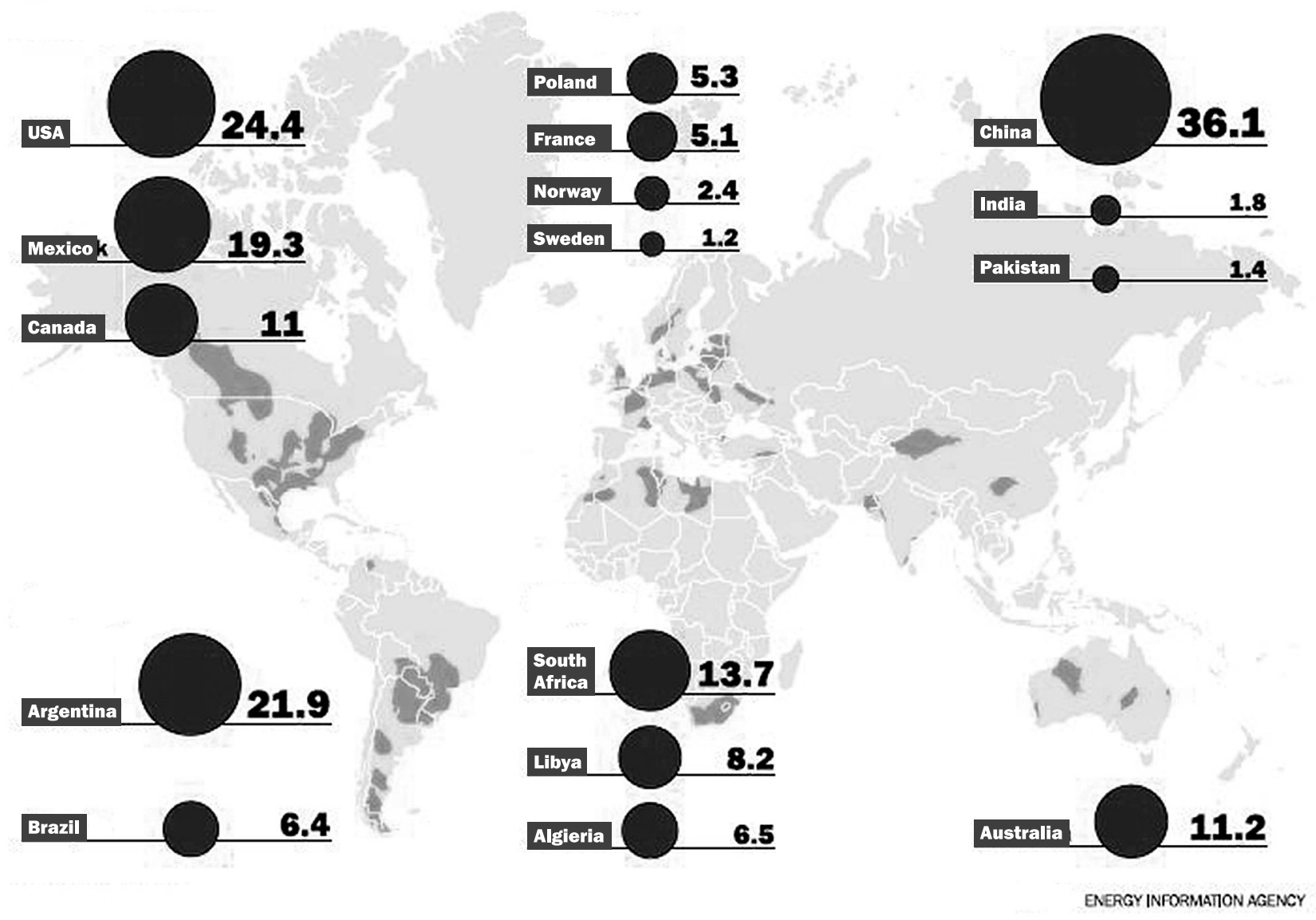

Fig. 7. Shale gas resources in the world (trillion $\mathrm{m}^{3}$ ) (after www.lupkipolskie.pl)

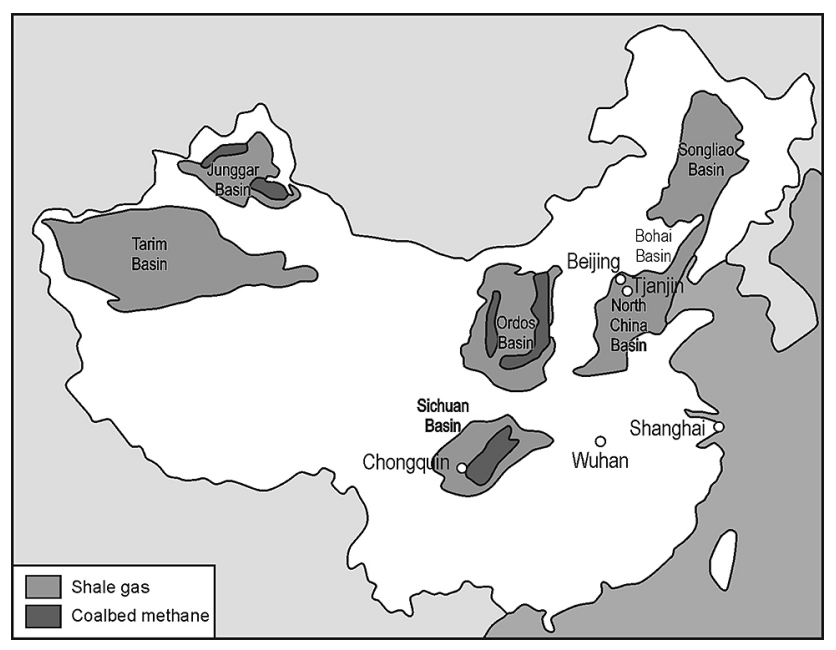

Fig. 8. Shale gas basins in China (after www.niezalezna.pl)

will still be enormous, and ultimately China could extract both gas and oil from shale. However, in the most prospective areas, i.e. the Tarim and Sichuan Basins (Fig. 8), difficulties are mounted: lack of sufficient road and pipeline infrastructure as well as problematic access to a sufficient quantity of water required in the process, and inaccessibility due to the terrain features.

\section{References}

BP Energy Review 2013.

Gabzdyl W., 1994. Geologia złóż węgla. Złoża Świata. Wyd. Pol. Agen. Ekolog. Warszawa.

Stupnicka E., 1978. Zarys geologii regionalnej świata. Wyd. Geol. Warszawa.

www.lupkipolskie.pl

www.mincom.home.pl

www.niezalezna.pl

www.nowastrategia.org.pl

www.sendzimir.metal.agh.edu.pl 